\title{
Monika Maron: Love and writing in a political climate
}

Mehr als Maron es sich eingestehen will, ist ihr Liebesroman ein Zeitroman, ja vielleicht der bis jetzt eindruckvollste deutsche Wenderoman.

(Anita Pollak) ${ }^{1}$

Jan van Luxemburg

Institute for Comparative Literature

University of Amsterdam

AMSTERDAM

The Netherlands

Abstract

Monika Maron: Love and writing in a political climate

This paper explores the relationship between the love story and official history in Animal triste by the German novelist Monika Maron. Despite suggestions that the love story could have happened at any time or place, a strong case can be made for a special interwovenness of the personal and the political in this Wende novel. Timelessness thus gives way to the intertwinement of a love story with a period in history, the Wende, the period of political change in Germany in 1989-1990. On the other hand, the love story's political dimensions contribute to another form of

1 "More than Maron admits to herself, her love-story is a novel of our time, maybe the most impressive German Wende-Novel until now" (Kurier, 1996-02-18).

I use the German word Wende ("transition"; Afr. "oorgang"), without translation, for the period between the fall of the Berlin Wall in the night of 8/9 November 1989 and the unification of both German states on 3 October 1990. During this time East Germany has been jokingly called: "Die noch DDR"; "The still GDR". I call the literature of around or during that period Wendeliteratur - without translating the term. $D D R$ is the acronym for "Deutsche Demokratische Republik", in English usually called "GDR": "German Democratic Republic".

I wish to thank Anneke van Luxemburg-Albers and Madeleine Kasten for their keen suggestions. I also wish to thank Leo Ikelaar of the German library of the University of Amsterdam, Das Deutsche Literaturarchiv in Marburg and the Pressedienst of the S. Fischer Verlag in Frankfurt am Main for their bibliographical and documentary help. I thank the referees of Literator for their helpful advice. All translations from the German are mine. 
timelessness, a kind of religious belief in the eternity of love. Before discussing Animal triste, I trace the relationship between love and politics in Maron's earlier novels.

\section{Introduction}

In 1996 the German writer Monika Maron published her fourth novel, Animal triste, the story of an amour fou in East Germany just after the Wende. Maron relates a passionate love affair, its ending and its fatal consequences.

The novel has received both praise and harsh criticism from German reviewers. Ulrich Schlacht describes the novel as a "great love story" ("großartige Liebesgeschichte"; Welt am Sonntag, 1996-02-18). According to Kerstin Hensel, Animal triste offers many opportunities for identification to women who have or have had a love affair with a married man (Freitag, 1996-02-23). Rainer Moritz is impressed with the intense and poetic description of physical desire, although he feels that the story of the love affair does not justify the intensity of the longing (Rheinische Merkur, 1996-02-23). Other critics, however, consider the novel close to kitsch, and Werner Fuld even characterises its tone as "whining and morose" ("wehleidig-muffig"; Die Woche 1996-02-16).

Exuberant praise came from Marcel Reich-Ranicki in the influential ZDF television program Das literarische Quartetl (1996-02-22) and in his review in the prominent German weekly Der Spiegel (1996-02-12). In his well-known authoritarian style, Reich-Ranicki declared Animal triste to be the most important love-story that he had read in years. In his opinion (Reich-Ranike, 1996:187) the book was:

... exceptional: exciting and effervescent and yet charming, passionate and hot-blooded, while nevertheless distinctive in its striking tranquility and maturity.

... außerordentlich: aufregend und aufbrausend und dennoch anmutig, hitzig und heißblutig und doch von erstaunlicher Ruhe und Reife.

This paper explores the relationship between the love story and official history in Animal triste. According to the jacket of the first edition, Animal triste is the report of the "radical change of life in a time of radical changes". Despite the suggestions of critics and of Maron herself that the love story could have happened at any time or place, I believe that a strong case can be made for the interwovenness of the personal and the political in this Wende novel, this novel of the German transition. Timelessness thus gives way to the intertwinement of a love story with a period in history. Moreover, the love story's political dimensions contribute to another form of timelessness, a kind of religious belief in the eternity of love. 
Animal triste was first published in February 1996. A shadow was cast on its reception by earlier reports in Der Spiegel and several daily papers about Maron's short cooperation with the Stasi. The uproar about these relevations has influenced and even biased several reviews of the novel. Jörg Magenau e.g. interprets the narrator's plea in Animal triste for the right to forget and for the therapeutic power of forgetting as an "indirect defence" for the way Maron has "forgotten" to come out about her Stasi period honestly and of her own accord (Wochenpost, 1996-02-22). However, from what I view as a literary perspective, a perspective that allows for literature's autonomy, confusing writer and narrator in such a way is rather unfortunate. ${ }^{2}$

\section{Combustion dust for Antigone}

Before we proceed to a further discussion of Animal triste, I will trace the intraliterary relationship between love and politics in Maron's earlier novels. The novel Flugasche ("Combustion dust"), when first submitted for publication, was rejected by East German censors and therefore published in West Germany in 1981 (Maron, 1995a). Flugasche contains a kind of Antigone theme: it relates a conflict between private and public duty or between woman and state. The

2 On 7 August 1996 Der Spiegel published an article disclosing that Monika Maron had cooperated with the Stasi under the name "Mitsu" from October 1977 until May 1978. The facts have been documented by Joachim Walther in his impressive work on the countless relations between the Stasi and German writers. The Stasi spied on writers, censored them, and tried to employ them at the same time (Walther, 1996: esp. 307-308 and 523-525). In the case of Maron nothing serious seems to have happened, but nobody who has admired Maron's courageous novels can possibly have welcomed the news. Nobody - Maron least of all - was happy about the episode.

In an emotional interview with Ursula Escherig, Maron stressed that she deserved some credit for her radical break with the party in which she grew up (in the DDR her stepfather was a minister of the interior):

[They should have accepted] that I had broken [with the system] unequivocally and without compromise. If such actions suddenly lose all meaning and hardly seem to have happened, I wonder: what are they really out for? They may be apostles of truth. But they clearly cared little about the nature of the truth.

[Man hatte akzeptieren müssen] daß ich ganz eindeutig und ohne Kompromisse meinen Bruch vollzogen habe. Aber als das plotzlich uberhaupt nichts mehr wert sein sollte, als das so gut wie ungeschehen war: da dachte ich: Worum geht es ihnen eigentlich? Das sind ja diese Wahrheitsapostel. Aber ganz offensichtlich ging es ihnen dabei nicht um Wahrheit (Escherig, 1996:/1). 
journalist Josefa Nadler makes a professional visit to the industrial town B. and is struck by the overwhelming impact of industrial waste on the life of its citizens. ${ }^{3}$ Josefa has a limited degree of freedom to write about this environmental problem. Eagerly pushing her limits, she opens her article with the line: " $\mathrm{B}$. is the filthiest town in Europe" ("B. is die schmutzigste Stadt Europas"; Maron, 1995a:36). In the ensuing conflict with editors and party bosses, she resigns from her prestigious and comfortable position and decides to earn a living as an assembly line worker instead. She refuses to make the compromises that her colleagues have learned to accept and is equally unwilling to submit to what we might call Creon's wishes.

Nevertheless, the intermingling of private and public life in this novel extends beyond its Antigonean conflict. On the one hand, Josefa tries to believe in the separation of private and public life. This becomes clear when she reflects on the night she has spent with her old friend Christian after returning from $B$.:

This night suddenly drew a straight line from her birth to her death and separated the natural from the absurd. Josefa found almost everything related to her profession on the side of the absurd; all these things seemed to her to be unnatural and designed to occupy her and others with a purpose that exceeded the scope of her natural life.

Diese Nacht plözlich zog eine gerade Linie von ihrer Geburt zu ihrem Tod, teilte Natürliches von Absurdem, und fast alles, was Josefas Beruf ausmachte, fand sie auf der Seite des Absurden, erschien ihr widernatürlich und ausgedacht, um sie und die anderen zu beschaffigen mit einem Sinn, der außerhalb ihres natürliches Lebens lag (p. 155-156).

After Josefa has abandoned her professional life, not even her love for Christian can help her. Though sympathetic to her public stand, he admonishes her to seek a professional compromise. She sends him away because his love no longer measures up to the standards of sovereignty and strength that she had come to expect (p. 239). She wants an absolute love like that of her Christian grandmother who followed her Jewish husband to the ghetto in Poland where the Nazis had banished him.

\section{Away from realism and back}

Die Überlauferin ("The [female] deserter"). Maron's next novel, was published in 1988 (Maron, 1995b). It is not the kind of political or Antigonean novel

3 The town in question can be identifiod as Bitterfeld in Sachsen-Anhalt 
suggested by the title. ${ }^{4}$ The issue goes way beyond a political desertion to encompass desertion from life itself. The protagonist, Rosalind, quits her job and stays home in her room in the Pankow quarter in East Berlin. Born during a bombing in World War II, she suffers from "insufficient lust for life" ("mangelhafte Lust zu leben"; Maron 1995b:16) and a fascination with death.5 In Die Überläuferin dreams, everyday life and hallucinations come together and get mixed. Rosalind seems split into two personalities: "Rosalind" herself, a woman in touch with society but always searching and insecure, and her friend Martha, an exploring, independent and even anarchistic woman. The narrative voice switches back and forth between the first and the third person and even gives way to dramatic dialogues in four interludes. This surrealist novel may rightly be described as Kafkaesque without resorting to the term's stereotypical use. It is legitimate to compare Rosalind, enclosed as she is in her Berlin room, to Gregor Samsa awakening in his room in "Die Verwandlung" ("The metamorphosis"; cf. Mahlendorf, 1988:256).

Like Kafka, Maron in Die Überläuferin does not adopt a transparent political position as was the case in the more direct and at times even journalistic Flugasche. However, the novel can be read as a political allegory and has been interpreted as such by reviewers including Elsbeth Pulver in the Neue Zürcher Zeitung and Jürgen P. Wallmann in Der Tagesspiegel (Schöning, 1993:15). To state censor Hauptmann Karlstedt of Hauptabteilung IX/2, a department of the Stasi, Die Überläuferin mediated "an impression of society thoroughly alien to socialism" ("[ein] zutiefst sozialimusfremdes Gesellschaftsbild"). He believed that publication in another country (i.e. the Federal Republic of Germany) would be an inimical action (Walther, 1996:307).

Given my interest in the absolute love of Animal triste and this passion's political intertwinement, mentioning the story of Hans and Ida, as remembered by Rosalind (p. 73-75), might be interesting. In the pre-war years, Hans broke off his happy, six-year long love affair with Ida because she was Polish and half Jewish. Rosalind muses that Hans' weakness and inability to prevail in the new political circumstances were clear to outsiders. The situation's romantic aspect, however, is far more complicated: perhaps Hans no longer loved Ida or had fallen for another woman. Maybe his political justification was less cruel to Ida

4 Die Üherlauferin contains hints of an Antigoncan theme around Martha, e.g., when a street theatre performs Antigone (p. 216).

5 Similar to Oskar in Günther Grass' The Tin Drum (Die Blechtrommel), she tries to avoid being bom by wrapping the umbilical cord around her neck (p. 15; ef. Mahlendorf, 1988:456). 
confession of lapsed love would have been. To her "the temporality of this love acquired its meaning through the barbarism of those days" (p. 75).

Stille Zeile Sechs was first published in 1991, some time after the Wende. Nevertheless, it is set in Berlin under the German Democratic Republic (Maron, 1995c). The novel's title refers to an address in an affluent East Berlin quarter, Das Städtchen, where party officials live: "Stille Zeile Sechs/Silent Row \# 6". In this novel Maron has switched back "from surrealism to realism" (Schmidt, 1994:247). Though love and lost love are never far away, Stille Zeile Sechs is first of all a political novel. In 1992, when Maron received the Kleist Prize for her novels Flugasche and Stille Zeile Sechs, Marcel Reich-Ranicki called Maron a goddess of vengeance ("eine Rachegöttin") in his baroque eulogy. $\mathrm{He}$ characterised her novel Stille Zeile Sechs as "an epic settlement, no longer with the DDR but with communism as such" ("eine epische Abrechnung nicht mehr mit der DDR, sondem mit dem Kommunismus"; Schöning, 1993:7).

This "epic settlement" crystallises into the confrontation between the historian Rosalind Polkowski, who has quit her job to do mindless clerical work (p. 18), and the retired party boss, Herbert Beerenbaum, whom she assists in writing his memoirs. She discovers that Beerenbaum once had her friend "The Count" "Der Graf") sent to prison for three years for smuggling a scholarly manuscript on Chinese literature out of the DDR. Rosalind confronts the old man with the facts. The same day Beerenbaum suffers a fatal heart attack, but only after trying to defend his action to Rosalind: "Your sinologist is a thief. A thief belongs in prison" ("Ihr Sinologe [ist] ein Dieb. Ein Dieb gehört ins Gefängnis", p. 206).

The love story in the background of Stille Zeile Sechs is the broken-off affair between Rosalind and her former husband Bruno. The facts of this ruptured relationship are related with great distance and irony, but Rosalind relates her satisfaction about Beerenbaum's death to another love story involving the tragedy of a thirty-year old worker in F. about whom she has read in the paper. Jilted by his inamorata, the worker could not bear that she live on without loving him: "Daß sie weiter lebte, ohne ihn zu lieben, konnte er nicht ertragen" (p. 209). So he killed her. Likewise, Beerenbaum seems to have lost the right to live.

\section{Animal triste: Love should not be missed}

Neither irony nor distance from love is to be found in Animal triste (Maron, 1996). The novel has more in common with the tragic story of the unhappy worker from F. in Stille Zeile Sechs. Such seriousness led Werner Fuld to describe the novel's love story, in an etymological pun, as "ohne Feuchtigkeit" i.e. "dry, humorless" (Die Woche, 1996-02-16). But what else can one expect? 
"Omne animal post coitum triste". 6 Readers are offered the story of an absolute love. Such a tale sometimes needs absolute terms and does not automatically contain the kind of humour Fuld seems to expect.

According to Maron, the advice from the critic Reich-Ranicki was among the factors that led her to write a real love story. She wanted to prove that she was not, as she had first suggested to Reich-Ranicki, "too shy or modest" ("zu schamhaft") to write a love story (Escherich, 1996:10-11). With the words of the workman from $F$. fresh in our minds, her accomplishment was predictable.

In Animal triste, the love story is narrated by a very old woman who looks back on what happened in the year of the Wende. A year prior to this political upheaval the narrator has suffered a mild stroke or loss of consciousness on the street. This moment marks a change in her life.

Had this attack not been the simulation of my death, and had I actually died that evening, what would I have missed? What else can one miss in life besides love? That was the answer.

Ware der Anfall nicht die Simulation meines Todes gewesen, sondern wäre ich an diesem Abend wirklich gestorben, was hätle ich versäumt? Man kann im Leben nichts versäumen als die Liebe. Das war die Antwort (p. 23; emphasis added).

The italicised words - "Man känn im Leben nichis versäumen als die Liebe" have been interpreted by most critics as the epitome of the book's thematics. The love story itself starts a year later in the Museum of Natural History, where the narrator works as a paleontologist. An enormous brachiosaurus is housed there. Franz, ${ }^{7}$ a West German active in the reorganization of the museums in Berlin, is there on a professional visit. He is one of the many West Germans who cross the border to reorganise the "Ossis". Franz and "she" meet in the room of the gigantic skeleton. Three words mark the beginning. His first words to the I persona are : "A beautiful animal" ("Ein schönes Tier"):

1 was not in search of [Franz] and had not expected him. One morning he simply appeared at my side. The brachiosaurus grinned down at us, just as

6 From the Latin translation of Aristotle's Problemara XXX 1: "Every animal is sad after making love."

7 The narrator cannot actually remember his name. She calls him Franz, a word that has the same dark sound to her as "Grab" ("grave") or "Sarg" ("coffin") p. 18). The symbolism is obvious but nevertheless telling. 
it had grinned down at me alone at other times, and Franz said softly and unforgettably: 'A beautiful animal.'

Ich habe [Franz] nicht gesucht, und ich habe ihn nicht erwartet. Eines Morgens stand er neben mir, der Brachiosaurus grinste auf uns beide herab wie sonst auf mich allein, und Franz sagte leise und unvergeßlich: 'Ein schönes Tier' (p. 23-24).

These three words become an oracle for her. In "Ein schönes Tier" she recognizes someone related to her, a person interested in the animal's life and not in its death. She answers "Yes, a beautiful animal." ("Ja, ein schönes Tier", p. 27.) She will remember this moment "two thousand times or more" as the most precious moment of her life. These words are the pledge of a love that must last forever. When Franz strokes her cheek with the back of two of his fingers some time later to show her what made him love her at first sight and what probably made her trust him ("It was this way": "Das war es", p. 37), she is strongly reminded of the time she first touched the brachiosaurus during a childhood visit to the museum: the start of a lifelong fascination.

Franz is a married man. His work makes it possible for him to visit her regularly, two or three times a week. Each time he has to leave her at half past midnight. At that instant he always asks her the time, even though he knows. Then he lights a pipe to dispel her scent before he goes back to his wife.

When Franz and his wife suddenly go on a holiday to Scotland to visit Hadrian's Wall - it may have been in the same summer or one or two years later: the narrator has forgotten such details - the woman is seized by jealousy. Feeling helpless and deserted, she watches in the hall of the airport as Franz and his petite blonde wife pass through customs and sees Franz smile kindly at his wife. When Franz telephones her a few days later, she cannot hide her jealousy. She vulgarly assures him that she hopes he cannot get an erection when he is with his wife. In what may be an indirect answer Franz tells her that Hadrian's Wall separated civilization from barbarism, words that to her symbolise her separation from Franz. In the following days, she tracks the holiday on a map and through tourist guides. She telephones all hotels along the road. Once she reaches the right hotel, but does not wait until Franz answers the telephone in his room.

Once the married couple is back in Berlin, she starts to follow Franz's wife. She waits in her car till the wife comes home; she follows her into the supermarket to see what she buys for Franz. Then one day she addresses the wife, has herself invited and tells about her love affair with Franz. This is the beginning of the end. The end of the book lends itself to several interpretations. The narrator remembers that Franz told her he no longer resented his father for leaving his mother for another woman. She does not remember whether Franz then drew the 
obvious conclusion regarding his own life. She thinks that she remembers that Franz left his things at her house and promised to come back and live with her. He even left his guitar in her room. That night at half past twelve, the ominous moment of all their love nights, she accompanies Franz to the bus stop; she realises that he will not return. In her memory she is unsure whether she pushed him, or whether he fell before being killed by the oncoming bus.

\section{Timelessness and time}

In Animal triste the narrator who relates the love story is a hundred years old. She tells the events she has lived through, fifty years ago, in the time that the "gangster band", the "band of criminals" ("Gangsterbande", p. 30; "Verbrecherbande", p. 43) was obliged to give up its power. Actually she is not sure whether she is a hundred years old or younger; she might as well be ninety or eighty or even less. The love story she remembers could also have happened forty or thirty or even fewer years ago. Through this hesitancy about time, the writer introduces a timeless quality in the narration and, on a thematic level, also in the time of the love tale. The events that occurred during the Wende period could have taken place at another time as well. Or could they? That is the question I am trying to answer here.

The narrator's former profession also inspires a sense of timelessness. Her main concern, as a paleontologist, is the skeleton of the brachiosaurus. This animal, another animal triste, has lived some one hundred and fifty million years ago, an impressive length compared to the forty-year history of the DDR or the short transition period after the Wende: forty years of "gang rule" ("Bandenherrschaft") in world historical perspective is even less than the time the brachiosaurus took to lift its foot (p. 31-32).

Counterbalancing these connotations of timelessness is a specific denotation of time: the time when Germany changed, die Wende. The love story of Animal triste starts in the summer after the Berlin wall came down, the summer of 1990. On several occasions the narrator connects private and love life with official life.

In the year of the Wende people in East Germany lost all certainty. Everything familiar changed:

There was new money, there were new passports, new authorities, new laws, new uniforms for the police, new stamps, new owners, who were in fact the old ones.

Es gab neues Geld, neue Ausweise, neue Behörden, neue Gesetze, neue Untformen fur die Polizei, neue Briefmarken, neue Besitzer, die eigentlich die alten waren (p. 89). 
People clung to what they had, to what they knew, especially in matters of the heart. Married couples about whom everybody knew that they were hardly on speaking terms suddenly appeared hand in hand. People on the verge of divorce reconciled their differences. Karin und Klaus are two such friends of the narrator's, who describes them with much cynicism and humour. One can mention the way Karin changes the articulation of her name "Lüderitz" when she answers the telephone, as her love life changes, and how she swaps her gardening outfit from a bikini to an old shirt of Klaus'. When the wall comes down, the couple forgets its problems and Klaus' adultery and appears hand in hand in front of the shop window of "Wiesenhavern am Ku'damm Ecke Knesebeckstraße" ( $p$. 97).

Others fall back on different familiar and trusted aspects of life. Her friend Emile breaks off his relationship with Sabine, a woman from West Berlin who always had to leave East Berlin by midnight, to take on a political career and a new partner in the East Berlin he knows and trusts. To the narrator, the fall of the Wall signifies the moment at which the love that had seemed on the verge of blossoming since her loss of consciousness a year ago breaks loose: "I met Franz": "Ich traf Franz" (p. 99). "I often believed", she says, "that the Berlin Wall had been destroyed exclusively to enable Franz to find me" ("Manchmal glaubte ich sogar, da $B$ auch die Mauer in Berlin nur eingerissen wurde, damit Franz mich endlich finden konnte", p. 51).

In her earlier novels Monika Maron meticulously documented life in communist East Berlin and its implications for everyday, professional and emotional life, perhaps nowhere so subtly as in Stille Zeile Sechs. In Animal triste as well, the extensive consequences of political claims and lack of freedom in everyday life are often manifest. I mention the impossibility for the narrator, in the days when she was working in the museum, to travel and to meet her academic peers in other countries or to visit the famous brachiosaurus relics at Pliny Moody's Garden in South Hadley, Massachusetts. On the other hand, these restrictions preserved her loyalty to her own brachiosaurus, a requirement for meeting Franz. Although Maron has stated in interviews that as a novelist she is no longer interested in the implications of the DDR politics (Escherig, 1996:10), this novel owes much of its interest to such connections between love and politics.

One such connection merits a more detailed description. Franz and she often sing together. Contrary to Franz's expectations, they know many of the same songs, like Laurentia, liebe Laurentia mein and Wahre Freundschaft (p. 103). But thanks to her communist education she does not know any religious songs. One night, when their love affair is still in its prime, she offers an alternative to Franz's church songs and sings the Stalin hymn in Russian, the way she learned it at school when she was eleven or twelve years old. She kneels while singing the 
song. In the process, she vaguely realises that she is making a mistake in singing this song and singing it this way: "twice dreadful, depraved in my faith and unbounded in my treason" ("doppelt furchtbar, verdorben im Glauben und hemmunglos im Verrat”, p. 105).

The blasphemous delivery of the Stalin hymn is not merely - as the narrator suggests - a pivotal scene in the love story. It is also crucial to my interpretation of Monika Maron's writings. The narrator regards the singing of the hymn as "wanton self-ridicule" ("mutwillige Selbstverhöhnung", p. 106). She suspects that Franz considers her rendition an attempt to hide the "void that the innocent grandiose mistake had left in her soul" ("das Nichts, das [ihr] unschuldiger grandioser Irrtum in [ihrer] Seele hinterlassen hatte"). When East meets West after forty or more years of separation, it becomes apparent that the two worlds have grown apart. We have learned of the political and economic aspects of the separation through papers and on television. The segregation has also permeated literature and the eternal theme in literature: love between two people.

However, the situation is more complex. According to the narrator, Franz no longer believes in his God but at least does not ridicule Him. His religious hymn asking God to guide him toward a happy and eternal hereafter ("führe mich bis an mein selig Ende und ewiglich", p. 106) still has a serious impact, in the sense that it can be interpreted as a statement about their love.

Franz considers the woman's rendition of the Stalin hymn both shocking and disloyal. In my interpretation, however, the kneeled performance as part of an exchange between lovers also consecrates her love in a manner reminiscent of John Donne's "The Canonisation", where love canonises the lovers to eternity. There is no reason to attribute - as the narrator does - all the power of religious performance to Franz. The woman's kneeled singing of the Stalin hymn, which elevates Stalin into eternity, can also be heard as a hymn of love. In a deconstructive way her "prayer" shows a means of hallowing love into a true eternity through the derision of the timeless pretenses of the communist period.

Thus timelessness and temporal boundaries twice come together. If we find a timeless love ("What else can one miss in life besides love?"), we cannot protect it from the implications of place and time, e.g. the implications of living in different parts of Germany or of the Wende. Time and place are responsible for having made people different even if they know every muscle and every nerve of each others' bodies, as Franz and "she" do. At the same moment the timelessness of the Stalin hymn exposes its own temporality while establishing the timelessness of love. 


\section{Bibliography}

Escherig, Ursula. 1996. Die Liebe, das andauernde Mysterium. Börsenblatt für den deutschen Buchhandlung, 163(13):9-11

Fuld, Werner. 1996. Die Woche, 1996-02-16. (Review of Animal triste.)

Hensel, Kerstin. 1996. Freitag, 1996-02-23. (Review of Animal triste.)

Magenau, Jörg. 1996. Wochenpost, 1996-02-22. (Review of Animal triste.)

Mahlendorf, Ursula. 1988. Der weiße Rabe fliegt: Zum Künstlerinnenroman im 20. Jahrhundert. In: Brinker-Gabler, Gisela, (ed.) Deutsche Literatur von Frauen. Vol. 2. München : Beck. p. 445-459.

Maron, Monika. 1995a (1981). Flugasche. Frankfurt aM. : Fischer.

Maron, Monika. 1995b (1988). Die Überlauferin. Frankfurt aM. : Fischer.

Maron, Monika. 1995c (1991). Stille Zeile Sechs. Frankfurt aM. : Fischer.

Maron, Monika. 1996. Animal triste. Frankfurt aM. : Fischer.

Moritz, Rainer. 1996. Rheinische Merkur, 1996-02-23. (Review of Animal triste.)

Pollak, Anita, 1996. Kurt, 1996-02-18. (Review of Animal triste.)

Reich-Ranicki, Marcel. 1996. Der Spiegel, 1996-02-12. (Review of Animal triste.)

Schlacht, Ulrich. 1996. Welt am Sonntag, 1996-02-18. (Review of Animal triste.)

Schmidt, Ricarda. 1994. From Surrealism to Realism: Monika Maron's Die Überläuferin und Stille Zeile Sechs. GeM, 31:247-255.

Schöning, Hella (ed.) 1993. Monika Maron. Pressedienst. Frankfurt aM. : Fischer. August 1993.

Walther, Joachim. 1996. Sicherungsbereich Literatur: Schriftsteller und Staatssicherheit in der Deutschen Demokratischen Republik. Berlin : Links. 